\title{
Homocystinuria: Observations on the Biosynthesis of Cystathionine and Homolanthionine
}

\author{
Gerald E. Gaull ${ }^{[23]}$, Yoshiro Wada, Karmela Sahneidman, David K. Rassin, \\ Harris H. Tallan, and John A. Sturman
}

\begin{abstract}
The Department of Pediatric Research, New York State Institute for Basic Research in Mental Retardation, Staten Island; the Departments of Pediatrics and Ophthalmology and the Clinical Research Center, Mount Sinai Hospital School of Medicine, New York; and the Departments of Pediatrics and Neurology, Columbia-Presbyterian Medical Center, New York, New York, USA
\end{abstract}

\section{Extract}

Patients with homocystinuria and a normal subject excreted cystathionine (1.8-15.0 $\mu$ moles $/ \mathrm{hr}$ ) after oral administration of homoserine plus cysteine; administration of both precursors is necessary. Excretion in the urine of the next higher homologue of cystathionine, homolanthionine, was found to occur spontaneously $(0.8-1.5 \mu$ moles / $\mathrm{hr}$ ), but not constantly, in three of seven patients with homocystinuria; loading with homoserine increased homolanthioninuria (2.9-5.7 $\mu$ moles $/ \mathrm{hr})$.

Optimum conditions were established in crude extracts of rat liver for in vitro synthesis of cystathionine from homoserine and cysteine (reverse cystathionase) and of homolanthionine from homoserine and homocysteine. Under these conditions, a greater capacity for synthesis of cystathionine by reverse cystathionase (1856 m $\mu$ moles/ $\mathrm{mg}$ protein $/ \mathrm{hr} \pm 95$ ) than for its cleavage in the forward direction (951 m $\mu$ moles $/ \mathrm{mg}$ protein $/ \mathrm{hr} \pm 26$ ) was demonstrated in liver; brain showed barely measurable activity in either direction. In crude extracts of livers from two patients with homocystinuria, activity of reverse cystathionase (39 and $56 \mathrm{~m} \mu$ moles/mg protein/hr) was less than cleavage ( 144 and $396 \mathrm{~m} \mu$ moles/mg protein $\mathrm{hr}$ ), and both activities were far less than that found in rat liver extracts under the same conditions.

Homolanthionine synthesis in rat brain was almost nil; in the other rat organs, it was far less than cystathionine synthesis by reverse cystathionase (compare 69 $\mathrm{m} \mu \mathrm{moles} / \mathrm{mg}$ protein $/ \mathrm{hr} \pm 2$ in rat liver); it was greater in extracts of rat liver than in extracts of human liver (6.7-10.8 $\mathrm{m} \mu$ moles $/ \mathrm{mg}$ protein $/ \mathrm{hr}$ in human liver); it was virtually absent from the liver of the vitamin $\mathrm{B}_{6}$-deficient rat, but activity was restored by pyridoxal phosphate added in vitro.

Homolanthionine synthesis activity in rat liver was separated from cystathionine synthase by ammonium sulfate fractionation (Table IX); it was not separated from cystathionase by such fractionation or by chromatography on carboxymethylcellulose (Fig. 3).

\section{Speculation}

Although administration of homoserine and cysteine results in urinary excretion of cystathionine by both normal subjects and those with homocystinuria, it is improbable that this treatment would promote the formation of any considerable amount of cystathionine in the brain, since evidence from rat studies indicates that the necessary 
enzymatic activity is extremely low in brain. Also, it is not likely that this procedure could produce the high optimum concentrations of homoserine in patients with homocystinuria. Homolanthionine synthesis is virtually absent in extracts of rat brain, suggesting that, whatever this compound may have to do with the pathogenesis of homocystinuria, it seems unlikely to have anything to do with brain dysfunction. The formation of homolanthionine in rat liver is not due to cystathionine synthase activity. Present evidence suggests that cystathionase, acting in the "reverse" direction, is responsible for homolanthionine synthesis.

\section{Introduction}

Cystathionine, an intermediate on the pathway of conversion of methionine to cysteine, is present in high concentrations in normal brain [17] but is virtually absent from the brain of patients with homocystinuria $[2,6]$. A deficiency of cystathionine synthase (EC. 4.2.1.21) (Fig. 1, reaction 1) in brain [11], as well as in liver [9], has been demonstrated in patients with homocystinuria. To provide cystathionine by feeding or injection is not practical, since it is handled by the kidneys as a "no-threshold" substance and is inordinately expensive; therefore, Wong, Schwarz, and Komrower [18] explored the therapeutic possibility that it could be synthesized in situ by reversal of cystathionase (EC. 4.2.1.15) (Fig. 1, reaction 3). They showed that in patients with homocystinuria, maintained on diets restricted in methionine, cystathionine was excreted in the urine following oral loads of cysteine and homoserine. They also demonstrated the synthesis of cystathionine from homoserine and cysteine in extracts of liver from these patients, as has been demonstrated to occur in crude extracts [3] and in partially purified preparations of rat liver $[3,8]$. They pointed out that

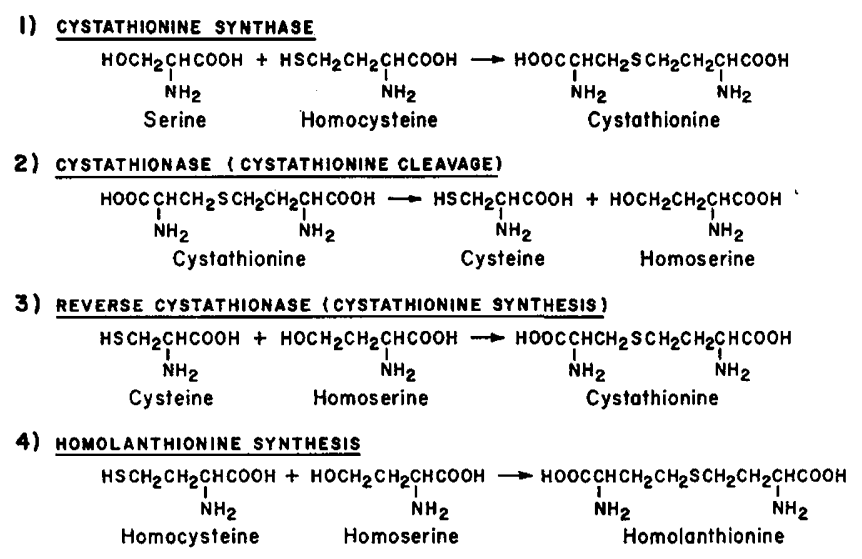

Fig. 1. Some reactions involved in the metabolism of cystathionine and homolanthionine. this therapeutic approach would be of potential value only if this process took place in the brain. They did not explore the problem further.

Homolanthionine, the next higher homologue of the thioether cystathionine ( $c f$. Fig. 1), was tentatively identified in the urine of seven patients with homocystinuria (from three unrelated families) by Perry, Hansen, and MacDougall [12]. It had been identified previously in bacteria by Huang [7]. One of the hypotheses put forward [12] to explain the genesis of this amino acid was that it was synthesized by a condensation of homocysteine and homoserine (Fig. 1, reaction 4) catalyzed by a defective cystathionine synthase, whose binding site for serine, a $\beta$-hydroxyamino acid, was presumably altered in a way that allowed it to accept the four-carbon $\gamma$-hydroxyamino acid, homoserine.

Our interest in the pathogenesis of homocystinuria, in the role of cystathionine in the brain, and in the mechanism of action of massive doses of vitamin $B_{6}$ in altering the metabolism of sulfur-containing amino acids in patients with homocystinuria prompted us to explore these observations further. We have confirmed and extended the results of Wong et al. [18], but we find that the reversal of cystathionase activity in liver is very difficult and that brain has virtually no capacity to synthesize cystathionine by this route.

The excretion and production of homolanthionine by affected subjects was not a constant finding, since we were able to identify homolanthionine in the urine of only three of seven patients with homocystinuria (from five unrelated families). The formation of homolanthionine from homoserine and homocysteine by the cystathionase of crude and partially purified extracts of rat liver was demonstrated.

\section{Methods}

Loading tests were performed orally using $200 \mathrm{mg} / \mathrm{kg}$ DL-homoserine and/or $100 \mathrm{mg} / \mathrm{kg}$ L-cysteine $\cdot \mathrm{HCl}$ administered in aqueous solution. Concentrations of free 
amino acids in the plasma and urine were determined by minor modifications of the method of Spackman, Moore, and Stein [13] using an automatic amino acid analyzer [19]. Plasma proteins were precipitated immediately with sulfosalicylic acid $(3 \%, \mathrm{w} / \mathrm{v})$ [4]. Homolanthionine was determined on the acidic and neutral column at an elution volume of $266 \mathrm{ml}$. The chromatographic position was determined by using authentic L-homolanthionine and was checked further by disappearance of the amino acid after oxidation of the urine with performic acid. In our experience, no other ninhydrin-positive compound is seen in this position when urine is analyzed.

Assays of the activity of cystathionine synthase and of cystathionase in the direction of cleavage of cystathionine (Fig. 1, reactions 1 and 2) were conducted according to methods previously described [5].

For assay of cystathionase in the direction of synthesis of cystathionine (reverse reaction), the following, in micromoles, were incubated at $37^{\circ}$ for $15 \mathrm{~min}$ in a

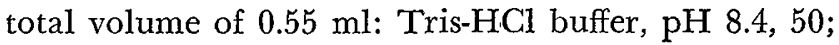
pyridoxal phosphate, 0.125 ; L-homoserine, 200; L-cysteine, 1.0. The crude extract was added in $0.1 \mathrm{ml} 0.03$ M potassium phosphate buffer, $\mathrm{pH}$ 6.9. The reaction was stopped by the addition of $1.0 \mathrm{ml}$ ice-cold trichloroacetic acid (TCA) $(10 \%, \mathrm{w} / \mathrm{v})$. Cystathionine was quantified on $6-\mathrm{cm}$ columns on an amino acid analyzer, as previously described in the assay for cystathionine synthase [5].

Conditions for the assay of the synthesis of homolanthionine were similar to those used for the assay of cystathionase in the direction of synthesis of cystathionine, except that DL-homocysteine, prepared as previously described [5], $10 \mu$ moles, and L-homoserine, $64 \mu$ moles, were used as substrates, and the incubation time was $135 \mathrm{~min}$. The reaction was stopped by the addition of $0.5 \mathrm{ml} 10 \%$ TCA. Homolanthionine produced was measured in the same manner as cystathionine, except that the eluting buffer was $0.2 \mathrm{M}$ sodium citrate, $\mathrm{pH}$ 3.60. Under these conditions, homolanthionine was eluted as a sharp ninhydrin-positive peak at $36 \mathrm{ml}$ (at a buffer flow rate of $50 \mathrm{ml} / \mathrm{hr}$ ) and was quantified by comparison with constants obtained by chromatographing authentic L-homolanthionine [20]. The ninhydrin color yield was $\mathbf{1 . 5}$ that of L-cystathionine, eluted as described above. Further steps for identification of homolanthionine as the product of the enzymatic reaction paralleled those used for cystathionine [5].

All patients homozygous for homocystinuria (referred to by initials) were described in a previous com- munication [5], except $M S$, who was a 20-year-old Jewish male with bilateral ectopia lentis, normal mentation, genu valgum, hypermethioninemia, homocystinemia, and enzymatically determined deficiency of cystathionine synthesis in the liver. On a regimen consisting of oral administration of $1.5 \mathrm{~g}$ pyridoxine $\cdot \mathrm{HCl} / 24 \mathrm{hr}$ and a controlled intake of about $15 \mathrm{mg} / \mathrm{kg} / 24 \mathrm{hr}$ methionine, hypermethioninemia and homocystinemia persisted.

\section{Results and Discussion}

\section{Excretion of Cystathionine}

The observation that acute oral loads of homoserine plus cysteine increase excretion of cystathionine in the urine of patients with homocystinuria [18] was confirmed in four patients (Table I: $M C, R C, L e P$, and $L a P$ ), in all of whom the diagnosis was established by direct assay of cystathionine synthase activity in liver [5]. Repeated loads given to siblings (Table I: $L e P$, and $L a P$ ) after successful treatment with massive doses of vitamin $B_{6}$ showed changes in the opposite direction. There was a wide range of response among the four untreated patients with homocystinuria; of the two normal controls loaded under the same conditions, one showed no measurable excretion of cystathionine and the other exhibited excretion levels falling in the middle of the range of the patients with homocystinuria.

In a fifth patient (Table II, $L M$ ) administration of either homoserine or cysteine alone did not elicit excretion of cystathionine in the urine, but when both precursors were given, cystathionine appeared. At no time during the 24-hr period following the loads of cysteine or of cysteine plus homoserine in $L M$ was cystine excreted in the urine in measurable quantities.

Table I. Excretion of cystathionine in urine after oral loads of DL-homoserine plus L-cysteine $\cdot \mathrm{HCl}$.

\begin{tabular}{|c|c|c|}
\hline \multirow{2}{*}{ Patient } & Base-line rate & 0 - to $4-\mathrm{hr}$ rate \\
\hline & \multicolumn{2}{|c|}{$\mu \mathrm{moles} / \mathrm{hr}$} \\
\hline Control $A$ & 0 & 0 \\
\hline Control $B$ & 0 & 9.7 \\
\hline$M C$ & 0 & 3.2 \\
\hline$R C$ & 0 & 10.8 \\
\hline$L e P$ & 0.1 & 15.0 \\
\hline$L e P^{1}$ & Trace & 5.4 \\
\hline$L a P$ & Trace & 1.8 \\
\hline$L a P^{2}$ & 1.8 & 10.0 \\
\hline
\end{tabular}

1 Pyridoxine $\cdot \mathrm{HCl}$ administered, $500 \mathrm{mg} / 24 \mathrm{hr}$.

2 Pyridoxine. $\mathrm{HCl}$ administered, $250 \mathrm{mg} / 24 \mathrm{hr}$. 
Table II. Excretion of some sulfur-containing amino acids in urine after oral loads of DL-homoserine, L-cysteine, or both in patient $L M$.

\begin{tabular}{|c|c|c|c|c|c|c|c|}
\hline \multirow{2}{*}{\multicolumn{2}{|c|}{ Load }} & \multirow{2}{*}{ Time, hr } & \multirow{2}{*}{$\begin{array}{l}\text { Urinary output, } \\
\mathrm{ml} / \mathrm{hr}\end{array}$} & Methionine & Homocystine & Cystine & Cystathionine \\
\hline & & & & \multicolumn{4}{|c|}{$\mu \mathrm{moles} / \mathrm{hr}$} \\
\hline \multirow{4}{*}{\multicolumn{2}{|c|}{ DL-Homoserine }} & $-10-0$ & 54 & 17.9 & 15.5 & 0 & 0 \\
\hline & & $0-4$ & 114 & 21.2 & 10.1 & 0 & 0 \\
\hline & & $4-8$ & 93 & 15.2 & 6.6 & 0 & 0 \\
\hline & & $8-24$ & 37 & 10.1 & 10.5 & 0 & 0 \\
\hline \multirow{4}{*}{\multicolumn{2}{|c|}{$\mathrm{x}$-Cysteine $\cdot \mathrm{HCl}$}} & $-10-0$ & 69 & 12.6 & 7.4 & 0 & 0 \\
\hline & & $0-4$ & 90 & 16.8 & 5.0 & 0 & 0 \\
\hline & & $4-8$ & 165 & 17.4 & 4.9 & 0 & 0 \\
\hline & & $8-24$ & 60 & 7.4 & 9.2 & 0 & 0 \\
\hline \multirow{4}{*}{\multicolumn{2}{|c|}{$\begin{array}{l}\text { DL-Homoserine plus L-cysteine. } \\
\mathrm{HCl}\end{array}$}} & $-10-0$ & 34 & 10.3 & 8.0 & 0 & 0 \\
\hline & & $0-4$ & 163 & 18.5 & 5.6 & 0 & 0 \\
\hline & & $4-8$ & 80 & 15.2 & 3.5 & 0 & 2.1 \\
\hline & & $8-24$ & 61 & 19.3 & 10.3 & 0 & 0.2 \\
\hline
\end{tabular}

We have no ready explanation of this enigma but suspect it is related to the fact that many untreated patients with homocystinuria show low or virtually zero concentrations of cystine in the plasma. The excretion of methionine and homocystine following the combined loads of homoserine plus cysteine followed no consistent pattern, in this patient as well as in the other four patients in whom the combined load was performed (but not reported in detail).

In all five patients, the plasma concentrations of homocystine and methionine (if there was also hypermethioninemia) showed a transient decrease during the period of the combined homoserine and cysteine load. However, $L M$ showed a striking, albeit temporary decrease in concentration of homocystine in the plasma, unaccompanied by an increase in the mixed disulfide homocysteine-cysteine, when loaded with cysteine alone. Loading with homoserine alone failed to alter concentrations of amino acids in plasma in a significant or consistent way. The decrease in homocystine and methionine concentrations may, in part, be a nonspecific phenomenon, since a decrease in the concentrations of glycine, alanine, and phenylalanine (three other amino acids chosen at random) also occurred during the combined load (Table III). Since the effect was most striking when homoserine and cysteine were administered together, and since the rate of excretion of urine invariably increased following the combined load (Table II), it was presumed that this decrease was, at least in part, an artifact due to transient hemodilution, the result of the osmotic effect of the load. Furthermore, giving one of the patients the same amount of homoserine plus cysteine in split doses during the day for a period of 2 weeks did not result in any alteration of the concentrations of methionine or homocystine in the plasma. This artifact was not so apparent in the experiments reported by Wong and co-workers [18], since they administered loads to patients whose concentrations of methionine and homocystine in plasma were controlled by means of dietary restriction. It was also notable that chronic administration of homoserine plus cysteine did not result in a discernible cystathioninuria. Cystathioninemia was not observed in any of the loading tests.

In patients $L e P$ and $L a P$, who showed an apparently complete response to massive doses of pyridoxine on an ad libitum diet $[1,5]$ (e.g., disappearance of hypermethioninemia and homocystinemia with reappearance of normal concentrations of cystine in the plasma), there was a striking effect of pyridoxine on the rise in concentrations of cystine in the plasma after administration of cysteine $\cdot \mathrm{HCl}$ plus homoserine orally (Table IV). Without pyridoxine there was virtually no cystine in the plasma at zero time, the rise in the concentration of cystine in plasma was small, and there was a return to resting levels by $4 \mathrm{hr}$. Whether this reflects an effect of vitamin $B_{6}$ on absorption of cystine from the gut or is a reflection of a diminished pool of cystine in the untreated state (e.g., a "sponge" effect) is not clear. Patients $M S$ and $L M$, who had no discernible response to massive doses of pyridoxine [5], showed tolerance curves of cystine before treatment with pyridoxine which were higher than those of $L e P$ and $L a P$ after treatment. After treatment they showed lower cystine tolerance curves. An explanation of these results is not yet apparent. 
Table III. Concentrations of some sulfur-containing and other amino acids in plasma after oral loads of DL-homoserine, L-cysteine, or both in patient LM

\begin{tabular}{|c|c|c|c|c|c|c|c|}
\hline \multirow{2}{*}{ Load } & \multirow{2}{*}{ Time, $\mathrm{hr}$} & Methionine & Homocystine & Cystine & Glycine & Alanine & Phenylalanine \\
\hline & & \multicolumn{6}{|c|}{$\mu$ moles $/ 100 \mathrm{ml}$} \\
\hline \multirow[t]{5}{*}{ DL-Homoserine } & 0 & 58.5 & 2.3 & 0 & 23.8 & 44.6 & 5.9 \\
\hline & 1 & 60.5 & 1.7 & 0 & 24.4 & 62.6 & 7.9 \\
\hline & 2 & 54.2 & 2.6 & 0 & 20.0 & 42.7 & 5.2 \\
\hline & 4 & 59.0 & 2.8 & 0 & 21.9 & 37.8 & 7.2 \\
\hline & 24 & 55.5 & 2.5 & 0 & 17.7 & 42.5 & 7.2 \\
\hline \multirow{5}{*}{ L-Cysteine $\cdot \mathrm{HCl}$} & 0 & 56.5 & 2.2 & 0 & 20.9 & 37.7 & 6.1 \\
\hline & 1 & 51.3 & 0.6 & 10.8 & 7.4 & 16.5 & 3.0 \\
\hline & 2 & 55.6 & 1.3 & 6.8 & 18.1 & 40.2 & 5.8 \\
\hline & 4 & 54.3 & 1.6 & 6.8 & 18.7 & 43.3 & 5.8 \\
\hline & 24 & 51.7 & 2.6 & 0 & 16.0 & 47.0 & 8.7 \\
\hline \multirow{5}{*}{$\begin{array}{l}\text { DL-Homoserine plus L-cysteine. } \\
\text { HCl }\end{array}$} & 0 & 60.1 & 3.3 & 0 & 24.3 & 41.4 & 8.9 \\
\hline & 1 & 55.8 & 1.2 & 7.3 & 18.0 & 47.8 & 5.3 \\
\hline & 2 & 26.8 & 0.5 & 11.8 & 9.2 & 30.6 & 4.0 \\
\hline & 4 & 39.7 & 0.8 & 11.0 & 14.6 & 31.3 & 7.6 \\
\hline & 24 & 50.6 & 1.3 & 0 & 17.5 & 39.9 & 5.9 \\
\hline
\end{tabular}

Table IV. Concentrations of cystine in plasma after oral loads of $\mathrm{L}$-cysteine plus DL-homoserine, with and without pyridoxine treatment

\begin{tabular}{|c|c|c|c|c|c|}
\hline \multirow{3}{*}{ Patient } & \multirow{3}{*}{ Treatment } & \multicolumn{4}{|c|}{ Time after loading, hr } \\
\hline & & 0 & 1 & 2 & 4 \\
\hline & & \multicolumn{4}{|c|}{$\mu$ moles $/ 100 \mathrm{mI}$} \\
\hline \multirow[t]{2}{*}{$L e P$} & $\mathrm{~B}_{6}$ & 3.3 & 9.2 & 10.8 & 7.1 \\
\hline & - & 0 & 0.8 & 1.7 & 0.4 \\
\hline \multirow[t]{2}{*}{$L a P$} & $\mathrm{~B}_{6}$ & 3.7 & 10.0 & 12.5 & 8.3 \\
\hline & - & 0 & 1.7 & Trace & 0 \\
\hline \multirow[t]{2}{*}{$M S$} & $\mathrm{~B}_{6}$ & 0 & 0 & 16.9 & 12.1 \\
\hline & - & 0 & 4.9 & 22.2 & 30.7 \\
\hline \multirow[t]{2}{*}{$L M$} & $\mathrm{~B}_{6}$ & 1.7 & 10.4 & 17.0 & 10.1 \\
\hline & - & 4.5 & 20.0 & 27.2 & 27.5 \\
\hline
\end{tabular}

\section{Excretion of Homolanthionine}

Only three of seven patients with homocystinuria (from five unrelated families) showed spontaneous homolanthioninuria (Table V), and this was not constant for at least one of them $(L e P)$. When $M S$ and $L a P$ were loaded with $200 \mathrm{mg} / \mathrm{kg}$ DL-homoserine, the rate of excretion of homolanthionine increased. At the time of the load, $M S$ was receiving $1.5 \mathrm{~g} / 24 \mathrm{hr}$ pyridoxine. $\mathrm{HCl}$, to which he had shown little, if any, biochemical response. A similar load of homoserine administered to $L M$, who exhibited no base-line homolanthioninuria, failed to elicit homolanthionine excretion. Patients $L a P$ and $L e P$ showed increased homolanthioninuria when loaded with homoserine plus cysteine. Thus it appears that the excretion of this compound in the urine of patients with homocystinuria is
Table $V$. Excretion of homolanthionine in urine of patients with homocystinuria

\begin{tabular}{|c|c|c|c|}
\hline Patient & Treatment & $\underset{\mathrm{hr}}{\text { Time, }}$ & $\begin{array}{c}\text { Homo- } \\
\text { lanthionine } \\
\text { in urine, } \\
\mu \text { moles } / \mathrm{hr}\end{array}$ \\
\hline$L M$ & DL-Homoserine & $\begin{array}{l}\text { Base line } \\
0-4 \\
4-8 \\
8-24\end{array}$ & $\begin{array}{l}0 \\
0 \\
0 \\
0\end{array}$ \\
\hline$M S$ & $\begin{array}{l}\text { DL-Homoserine (re- } \\
\text { ceiving pyridoxine. } \\
\text { HCl, } 1.5 \mathrm{~g} / 24 \mathrm{hr} \text { ) }\end{array}$ & $\begin{array}{l}\text { Base line } \\
0-4 \\
4-8 \\
8-24\end{array}$ & $\begin{array}{l}0.8 \\
2.3 \\
5.7 \\
2.2\end{array}$ \\
\hline$L a P$ & DL-Homoserine & $\begin{array}{l}\text { Base line } \\
0-4 \\
4-8 \\
8-24\end{array}$ & $\begin{array}{l}1.1 \\
3.0 \\
\frac{-}{1.2}\end{array}$ \\
\hline$L a P$ & $\begin{array}{l}\text { DL-Homoserine plus } \\
\text { L-cysteine } \cdot \mathrm{HCI}\end{array}$ & $\begin{array}{l}\text { Base line } \\
0-4 \\
4-8 \\
8-24\end{array}$ & $\begin{array}{l}1.5 \\
2.9 \\
0 \\
0.2\end{array}$ \\
\hline $\operatorname{LeP}$ & $\begin{array}{l}\text { DL-Homoserine plus } \\
\text { L-cysteine.HCl }\end{array}$ & $\begin{array}{l}\text { Base line } \\
0-4 \\
4-8 \\
8-24\end{array}$ & $\begin{array}{c}1.3 \\
\text { Trace } \\
1.0 \\
3.4\end{array}$ \\
\hline$L e P$ & - & & 0 \\
\hline$P M c K$ & - & & 0 \\
\hline$R C$ & - & & 0 \\
\hline$M C$ & - & & 0 \\
\hline
\end{tabular}

an inconstant phenomenon, perhaps dependent upon availability of substrate. Assuming the excretion of about $1 \mathrm{~g}$ creatinine $/ 24 \mathrm{hr}$, the rates of excretion of homolanthionine by these patients are of the same 
order of magnitude as those reported by Perry et al. [12].

\section{In Vitro Synthesis of Cystathionine and Homolan- thionine}

It seemed clear that patients with homocystinuria can synthesize cystathionine from homoserine and cysteine with fair consistency. Whether this reaction could take place in brain tissue was unanswered by the work of Wong et al. [18]. Furthermore, although patients with homocystinuria can excrete homolanthionine [12], our results suggest that it is not necessarily a constant finding. Therefore, it was decided to determine systematically the optimum conditions under which cystathionine and homolanthionine are synthesized in various tissues in vitro.

Factors affecting in vitro synthesis of cystathionine from homoserine and cysteine. As in the forward cystathionase (cystathionine-cleaving) reaction [5], the production of cystathionine from homoserine and cysteine (reverse cystathionase) was proportional to the amount of enzyme added (measured as total soluble protein) to approximately $0.5-0.6 \mathrm{mg} /$ tube for crude extract of rat liver. The course of the reverse reaction, however, remained linear only up to $15 \mathrm{~min}$, compared with 30 min with similar preparations in the cystathioninecleaving reaction. The rate of production of cystathionine was greatest with $200 \mu$ moles L-homoserine and $1.0 \mu$ mole L-cysteine. For any amount of L-homserine, amounts of L-cysteine greater than $1.0 \mu$ mole resulted in increasing inhibition of the production of cystathionine. The large amount of homoserine required was not due to conversion to $\alpha$-oxobutyrate, since there was less than $0.1 \%$ conversion under these conditions. No cystathionine was produced in crude

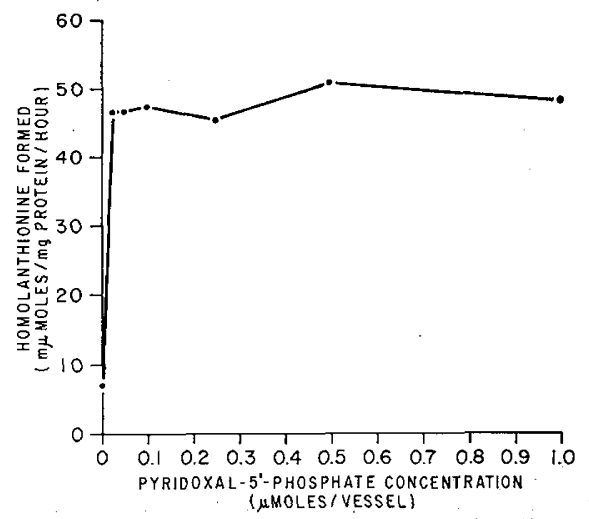

Fig. 2. Effect of pyridoxal $5^{\prime}$-phosphate on production of homolanthionine by a crude extract of rat liver. extracts of rat liver with the use of 7.5-30 $\mu$ moles $\alpha$-oxobutyrate in the presence of $1.0 \mu$ mole cysteine in the incubation mixture. The $\mathrm{pH}$ optimum and pyridoxal phosphate requirements for the reverse reaction were assumed to be the same as those of the forward reaction.

Factors affecting synthesis of homolanthionine from homoserine and homocysteine. With crude extracts of rat liver, the production of homolanthionine was proportional to the amount of enzyme added up to 1.0 $\mathrm{mg} /$ tube, rather than $0.5-0.6 \mathrm{mg} / \mathrm{tube}$, as in the forward and reverse cystathionase reactions. The course of the reaction remained linear up to $135 \mathrm{~min}$, compared with $15 \mathrm{~min}$ for the reverse cystathionase. The rate of reaction was maximum with $64 \mu$ moles L-homoserine and showed no difference with as much as 260 $\mu$ moles, compared with the reverse cystathionase reaction, which required $200 \mu$ moles for maximum activity. Furthermore, $10 \mu$ moles DL-homocysteine ( $5 \mu$ moles L-homocysteine) were required for maximum activity, compared with $1.0 \mu$ mole L-cysteine for the reverse cystathionase. Amounts of homocysteine beyond this resulted in an inhibition of synthesis of homolanthionine, just as amounts of L-cysteine beyond $1.0 \mu$ mole resulted in inhibition of the synthesis of cystathionine in the reverse cystathionase assay. The production of homolanthionine showed the same dependence on the presence of pyridoxal phosphate as did the activity of cystathionase [5], with the same optimum at 0.125 $\mu$ mole in crude extracts of rat liver (Fig. 2). Omission of pyridoxal phosphate resulted in $16 \%$ of the maximum synthesis which was attained with $0.125 \mu$ mole. No homolanthionine was formed when crude extracts were boiled or when either substrate was omitted. The substitution of serine for homoserine, under optimum conditions, resulted in the formation of cystathionine. The addition of L-threonine, in amounts equimolar to L-homoserine, did not yield any ninhydrin-positive product, suggesting that the compound tentatively identified by Perry et al. [12] was indeed homolanthionine rather than $\beta$-methylcystathionine.

Enzymatic synthesis of cystathionine from homoserine and cysteine by various tissues. When optimum concentrations of substrate were used, the rate of synthesis of cystathionine by cystathionase in crude extracts of rat liver was greater than the rate of cleavage of cystathionine (Table VI), although the amount of homoserine required to reverse cystathionase activity and produce cystathionine was extraordinarily high. There was very little synthesis of cystathionine from homoserine and cysteine by crude extracts of rat brain. 
Thus, even if the extraordinary optimum conditions could be duplicated in vivo, it seems unlikely that this reaction could replenish the decreased pool of free cystathionine in the brain of the patient with homocystinuria, since cystathionase activity is relatively low in the brain of all species studied so far [10, 16].

Using the same conditions which in crude extracts of rat liver were optimum for the cleavage of cystathionine or for its production from homoserine and cysteine, respectively, crude extracts of the liver of a patient with homocystinuria $(L M)$ were examined before and during treatment with massive doses of pyridoxine (Table VII). As expected, there was much less synthesis of cystathionine from homoserine and cysteine and much less cystathionine cleavage than in crude extracts of rat liver, since the liver of the human contains only one-eighth the cystathionase activity of the liver of the rat $[10,16]$.

In contrast to rat liver, however, cystathionine synthesis from homoserine and cysteine was less than cystathionine cleavage. Since insufficient tissue was available to establish optimum conditions for assay of cystathionase activity in human liver, conditions optimum in crude extracts of rat liver were assumed to be valid. The cleavage of cystathionine by cystathionase was strikingly increased after pyridoxine treatment. As previously reported [5], this occurs without an increase in cystathionine synthase activity and, in this patient, with no apparent salutary effect of pyridoxine treatment on the concentrations of the sulfur-containing amino acids in the plasma. However, there was no increase in activity of cystathionine synthesis from homoserine plus cysteine (reverse cystathionase) during pyridoxine treatment (there was a $30 \%$ decrease). These findings may have occurred because conditions were not optimum. Crude extract of grossly normal
Table VI. Activity of cystathionase in organs of the rat ${ }^{1}$

\begin{tabular}{lccc}
\hline \multirow{2}{*}{ Organ } & $\begin{array}{c}\text { Cystathionine } \\
\text { cleavage }\end{array}$ & $\begin{array}{c}\text { Cystathionine } \\
\text { synthesis }\end{array}$ & $\begin{array}{c}\text { Homolanthionine } \\
\text { synthesis }\end{array}$ \\
\cline { 2 - 4 } m $\mu$ moles/mg protein/hr \\
\hline Liver & $951 \pm 26^{2}$ & $1856 \pm 95$ & $69 \pm 2$ \\
Kidney & $467 \pm 21$ & $664 \pm 108$ & $18 \pm 2$ \\
Pancreas & $419 \pm 50$ & $541 \pm 82$ & $26 \pm 7$ \\
Brain & $16 \pm 3$ & $20 \pm 5^{3}$ & $0.10 \pm 0.06$ \\
\hline
\end{tabular}

${ }^{1}$ All values are calculated from duplicate observations on four animals, except as noted.

${ }^{2}$ Mean $\pm \mathrm{se}$.

${ }^{3}$ Calculated from duplicate observations on three animals.

liver from a 4-year-old patient with neuroblastoma showed forward and reverse cystathionase activities similar to those of $L M$ prior to treatment with vitamin $B_{6}$. Crude extract of liver from a newborn infant had low activities of cystathionase; this is a characteristic of human fetal, premature, and newborn liver [15].

Enzymatic synthesis of homolanthionine from homoserine and homocysteine by various tissues. The amounts of homolanthionine synthesized by various tissues in the rat were much less than the analogous synthesis of cystathionine, but the relative amounts synthesized by the tissues were similar (Table VI). The activity in brain was virtually nil. If the same conditions exist in humans, one may question whether this compound is responsible for the mental changes seen in homocystinuria. Synthesis of homolanthionine was measured in a biopsy of liver from patient $L M$ only after he was administered massive doses of pyridoxine. Homolanthionine was produced (Table VII), but the amount may have been underestimated, since the conditions for cystathionine synthase assay (essentially using $0.015 \mu$ mole pyridoxal phosphate rather than 0.125 ) were used. A crude extract of rat liver assayed at

Table VII. Cystathionase activity in crude extracts of human liver

\begin{tabular}{|c|c|c|c|c|}
\hline \multirow{2}{*}{ Patient } & \multirow{2}{*}{ Treatment } & $\begin{array}{c}\text { Cystathionine } \\
\text { cleavage }\end{array}$ & $\begin{array}{l}\text { Cystathionine } \\
\text { synthesis }\end{array}$ & $\begin{array}{l}\text { Homolanthionine } \\
\text { synthesis }\end{array}$ \\
\hline & & \multicolumn{3}{|c|}{$\mathrm{m} \mu \mathrm{moles} / \mathrm{mg}$ protein $/ \mathrm{hr}$} \\
\hline$L M$ & - & 144 & 56 & - \\
\hline$L M$ & Pyridoxine $\cdot \mathrm{HCl}^{1}(1 \mathrm{~g} / 24 \mathrm{hr})$ & 396 & 39 & $9.7^{2}$ \\
\hline 1-day-old full term infant ${ }^{3}$ & - & 9.8 & 1.4 & 10.8 \\
\hline$M Y, 4$-year old with neuroblastoma & - & 101 & 81 & 8.8 \\
\hline $\mathrm{CH}^{4}$ & - & 121 & - & 10.0 \\
\hline
\end{tabular}

1 Biopsy taken after 3 months of treatment.

2 This value is a minimal estimate since $0.015 \mu$ mole pyridoxal phosphate was used by error in this experiment instead of the optimal 0.125 mmole (cf. Methods).

${ }^{3}$ Frozen postmortem specimen taken $1.5 \mathrm{hr}$ after death from a 3450 -g newborn infant dying $6.75 \mathrm{hr}$ after birth from an intraabdominal hemorrhage produced by an intraumbilical catheter.

${ }^{4}$ An 18-year-old patient probably heterozygous for homocystinuria. 
Table VIII. Activity of cystathionase in liver of vitamin $\mathrm{B}_{6}$-deficient rats

\begin{tabular}{ccccccc}
\hline Rat no. & $\begin{array}{c}\text { Cystathionine } \\
\text { cleavage }^{1}\end{array}$ & \multicolumn{3}{c}{$\begin{array}{c}\text { Cystathionine } \\
\text { synthesis }^{1}\end{array}$} & $\begin{array}{c}\text { Homolanthionine } \\
\text { synthesis }^{1}\end{array}$ \\
\cline { 2 - 7 } & \multicolumn{5}{c}{ m $\mu$ moles/mg protein/hr } \\
\hline & - & + & - & + & - & + \\
\hline $1^{2}$ & 35 & 605 & 40 & 448 & 0 & 15.7 \\
$2^{2}$ & 12 & 616 & 23 & 760 & 0 & 20.8 \\
$3^{3}$ & 324 & 591 & 326 & 708 & 1.6 & 24.6 \\
\hline
\end{tabular}

1 - : assayed without addition of pyridoxal phosphate; +: optimal amount of pyridoxal phosphate added in assay.

${ }^{2}$ Vitamin $B_{6}$-deficient diet fed for 20 weeks.

${ }^{3}$ Vitamin $B_{6}$-deficient diet fed for 3 weeks.

the same time, under the same conditions, gave a value of $12 \mathrm{~m} \mu$ moles homolanthionine/mg protein $/ \mathrm{hr}$ rather than the expected $69 \mathrm{~m} \mu$ moles/mg protein/hr (cf. Table VI). The newborn infant's liver had easily measurable activity of homolanthionine synthesis despite low cystathionase activity in both forward and reverse direction. This was in striking contrast to the findings in patients $M Y$ and $C H$, each of whom had activities of homolanthionine synthesis in the same range as the newborn infant, but who had 10 times greater activity of cystathionine cleavage.

Is homolanthionine synthesized by a separate en$z y m e$ ? The similarities in behavior and in distribution of the enzymatic activity which synthesized homolanthionine from homoserine and homocysteine and that which synthesized cystathionine from homoserine and cysteine suggests that these two activities, at least in rat liver, may be identical. In other words, homolanthionine is synthesized by cystathionase acting in the direction of synthesis, rather than by cystathionine synthase. Thus, the synthesis of homolanthionine and that of cystathionine by cystathionase are both strikingly dependent on pyridoxal phosphate (Fig. 2), whereas cystathionine synthesis by cystathionine synthase in crude extracts is not $[5,10]$. This point was further illustrated by measuring the activities in the livers of vitamin $\mathbf{B}_{6}$-deficient rats (Table VIII). When the assays were carried out in the absence of added pyridoxal phosphate, activities of cystathionase (both forward and reverse) and of synthesis of homolanthionine were low or absent. Activity of all three functions was restored by addition of the optimum amount of pyridoxal phosphate to the assay medium, suggesting that the deficiency of activity of the holoenzyme was largely due to deficiency of the coenzyme. In contrast, cystathionine synthase activity in the liver of vitamin $B_{6}$-deficient rats is not decreased [14].
Direct evidence that synthesis of homolanthionine is not a function of cystathionine synthase was obtained by fractionation of a crude rat liver extract. Essentially all of the cystathionine synthase activity appeared in the protein fraction precipitated between 30 and $45 \%$ saturation with ammonium sulfate; almost all of the cystathionase activity and the homolanthionine synthesis activity appeared in the fraction precipitated between 55 and $70 \%$ saturation (Table IX). Chromatography of the $55-70 \%$ ammonium sulfate fraction on a column of carboxymethylcellulose removed the bulk of the protein but failed to separate the two enzymatic activities (Fig. 3). Preliminary experiments with electrophoresis on starch blocks have also failed to show any separation of these two activities. Further purification of cystathionase is necessary to demonstrate unequivocally that the two activities reside in the same protein molecule; such studies are under way in this laboratory.

Table IX. Fractionation of crude rat liver extract with ammonium sulfate

\begin{tabular}{cccc}
\hline $\begin{array}{c}\text { Ammonium } \\
\text { sulfate } \\
\text { saturation, } \%\end{array}$ & $\begin{array}{c}\text { Cystathionine } \\
\text { synthase }\end{array}$ & Cystathionase & $\begin{array}{c}\text { Homolanthionine } \\
\text { synthesis }\end{array}$ \\
\hline $0-30$ & 12 & $\mu$ moles $/ \mathrm{hr}$ & \\
$30-45$ & 756 & 6 & Trace \\
$45-55$ & Trace & 66 & Trace \\
$55-70$ & 0 & 3280 & 80 \\
$>70$ & 0 & 0 & \\
\hline
\end{tabular}

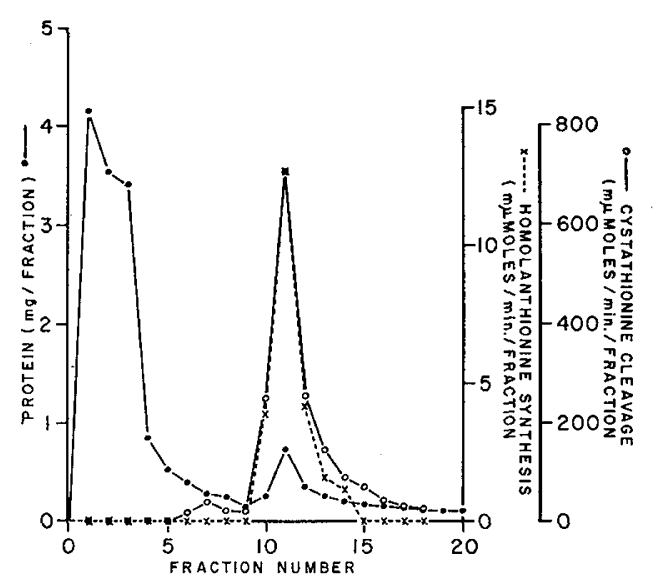

Fig. 3. Failure of chromatography on carboxymethylcellulose to separate cystathionase from homolanthionine synthesis activity. The enzyme preparation was applied to a $0.9-\times 13-\mathrm{cm}$ column of carboxymethylcellulose [21], equilibrated with $0.1 \mathrm{M}$ phosphate buffer, $\mathrm{pH}$ 5.4, and was eluted with a linear gradient made with $50 \mathrm{ml}$ each of $0.1 \mathrm{M}$ phosphate buffers of $\mathrm{pH} 5.4$ and 6.5. All buffers contained $10^{-3} \mathrm{M}$ ethylenedianninetetraacetate. The size of each fraction was $3.3 \mathrm{ml}$. 
The data on cystathionase activity of crude extracts of human liver do not permit definite conclusions concerning the identity of the three activities in man. Thus, in the crude extracts of liver from patient $L M$, cystathionine cleavage activity was more than doubled with pyridoxine treatment, whereas reverse cystathionase (cystathionine synthesis) was essentially unchanged. Furthermore, the ratio of homolanthionine synthesis to either cystathionine cleavage or synthesis was much greater in the newborn infant's liver than in the extracts from $L M$ or $M Y$ (Table VII). Since insufficient tissue was available to establish optimum conditions for assay of the human enzymes, final judgment must await purification of cystationase from human liver. The present findings, therefore, do not rule out the suggestion of Perry et al. [12] that homolanthionine is synthesized in man by an altered form of cystathionine synthase, but, on the basis of the results obtained, using partially purified preparations from rat liver, it appears more likely that its synthesis is catalyzed by cystathionase.

\section{References and Notes}

1. Barber, G. W., and Spaeth, G. L.: Pyridoxine therapy in homocystinuria. Lancet, $i$ : 337 (1967).

2. Brenton, D. P., Cusworth, D. C., and Gaull, G. E.: Homocystinuria: Biochemical studies of tissues including a comparison with cystathioninuria. Pediatrics, 35: 50 (1965).

3. Chatagner, F., Tixier, M., and Portemer, C.: Biosynthesis of cystathionine from homoserine and cysteine by rat liver cystathionase. Fed. Eur. Biochem. Soc. Lett., 4: 231 (1969).

4. Dickson, J. C., Rosenblum, H., and Hamilton, P. B.: Ion exchange chromatography of the free amino acids in the plasma of the newborn infant. Pediatrics, 36: 2 (1965).

5. Gaull, G. E., Rassin, D. K., and Sturman, J. A.: Enzymatic and metabolic studies of homocystinuria: Effects of pyridoxine. Neuropädiatrie, I: 199 (1969).

6. GerRitsen, T., AND Warsman, H. A.: Homocystinuria: Absence of cystathionine in the brain. Science, 145: 588 (1964).

7. Huang, H. T.: Accumulation of L-homolanthionine by an Escherichia coli mutant. Biochemistry, 2: 296 (1963).

8. Matsuo, Y., AND GReENberG, D. M.: A crystalline enzyme that cleaves homoserine and cystathionine. J. Biol. Chem., 234: 516 (1959).
9. Mudd, S. H., Finkelstein, J. D., IrReverre, F., and LAster, L.: Homocystinuria: An enzymatic defect. Science, 143: 1443 (1964).

10. Mudd, S. H., Finkelstein, J. D., IrreverRe, F., ANd Laster, L.: Transsulfuration in mammals. J. Biol. Chem., 240: 4382 (1965).

11. Mudd, S. H., Laster, L., Finkelstein, J. D., and Irreverre, F.: Studies on homocystinuria. In: H. E. Himwich, S. S. Kety, and J. R. Smythies: Amines and Schizophrenia, p. 247 (Pergamon, New York, 1967).

12. Perry, T. L., Hansen, S., ANd Macdougall, L.: Homolanthionine excretion in homocystinuria. Science, 152: 1750 (1966).

13. Spackman, D. H., Moore, S., and Stein, W. H.: Automatic recording apparatus for use in the chromatography of amino acids. Anal. Chem., 30: 1190 (1958).

14. Sturman, J. A., Cohen, P. A., AND Gauli, G. E.: Effects of deficiency of vitamin $B_{6}$ on transsulfuration. Biochem. Med., 3: 244 (1969).

15. Sturman, J. A., Gaull, G., and Räihä, N. C. R.: Absence of cystathionase in human fetal liver: Is cystine essential? Science, 169: 74 (1970).

16. Sturman, J. A., Rassin, D. K., and Gaull, G. E.: Distribution of transsulfuration enzymes in various organs and species. Int. J. Biochem., 1: 251 (1970).

17. Tallan, H. H., Moore, S., and STEIN, W. H.: L-Cystathionine in human brain. J. Biol. Chem., 230: 707 (1958).

18. Wong, P. W. K., Schwarz, V., and Komrower, G. M.: Biosynthesis of cystathionine in patients with homocystinuria. Pediat. Res., 2: 149 (1968).

19. Spinco model 116 or $120 \mathrm{C}$, Beckman Instruments, Palo Alto, Calif.

20. The generous gift of Dr. H. T. Huang, International Minerals and Chemical Corporation, Wasco, Calif.

21. Whatman CM52, H. Reeve Angel, Clifton, N. J.

22. Supported in part by the New York State Department of Mental Hygiene, Clinical Research Center Grant no. FR-71 of the National Institutes of Health, and National Institute of Neurological Diseases and Blindness Grant no. NB 03359. We are grateful to Drs. G. L. Spaeth and G. W. Barber for permission to study their patients ( $L a P$ and $L e P$ ), to Miss Marcia Kalin for expert nutritional advice, and to Miss Kathy Young and her staff for superb research nursing. Informed consent was obtained in accordance with the provisions set forth in the Declaration of Helsinki.

23. Requests for reprints should be addressed to: Gerald E. Gaull, M.D., Institute for Basic Research, 1050 Forest Hill Road, Staten Island, N. Y. 10314 (USA).

24. Accepted for publication August 19, 1970. 